\title{
Nepali Women in Comics
}

\author{
Promina Shrestha ${ }^{1 *}$
}

Published: April 11, 2020

\begin{abstract}
The following article is based on interviews and visual analysis of a collection of comics illustrated by Nepali women artists Bandana Tulachan, Kanchan Burathoki, Kripa Joshi, Preena Shrestha, Shraddha Shrestha and Sangee Shrestha, as well as my own work. These artists have been selected in terms of their visibility and prominence in the comics scene in Nepal. These artists have produced comics with personal narratives of their everyday life, thoughts and emotions. I address the questions if, through comics, individual visual accounts of the everyday experience can be understood as an act of feminism, and whether Nepali comics are a tool for encouraging feminist beliefs in Nepal. The article will give a brief introduction to Nepal's feminist movement and assess whether or not the comics, that have been studied, can be characterised as part of Nepali feminism. For the purpose of this paper, I have categorised my visual inquiry under the areas of satire as counter culture, body image, self expression and sexuality, real life, real issues, metaphors and the comical side of life.
\end{abstract}

Keywords: Nepal, Nepali Feminism, Nepali comics, Nepali women artists, personal narratives

\section{INTRODUCTION}

I was recently reading Nicola Streeten and Cath Tate's The Inking Woman: 250 years of women cartoon and comic artists in Britain (2018). It prompted me to think about women's comics in Nepal. In my understanding of western comics, there is an illustrious history of women making comics on women's issues, where comics have been used as a platform for gender activism, both through autobiographical and fictional works. This made me ask - who were these women that were creating such comics? What were their cultural and social backgrounds? What were their stories? Do they carry a feminist tone? I noticed that there was a knowledge gap in Nepal in terms of the historicity of women in comics and whether or not they address or partake in women's movements.

When I was asked to write a paper on Nepali women comics from a perspective of feminism my reaction was that it would be easy - just throw in the women I know, discuss their work in brief and say how representative they are of feminist ideas. However, that was not the case, and I could not have been more wrong, because Nepali feminism in itself is a complex issue.

\section{NEPAL'S FEMINISM IN BRIEF}

Nepal's feminist movement essentially ${ }^{1}$ started in the 1970s, and was based on the global idea of women in

\footnotetext{
${ }^{1}$ Nepal has undergone various political and social changes since the late 1940s, (Whelpton, 2005; Gellner, et al., 1997). Alongside these political movements and revolutions, Nepal's women's movement began and evolved alongside different political movements (see Whelpton, 2005; further reading Mahesh Chandra (Regmi Book Series) on detailed Nepali history) that Nepal has experienced from the 1950s to present. These have been categorised into five particular phases by Meena Acharya, starting from the late 1940s, 1951-1960, 1961-1990, 1991-2005 and 2006 (Acharya, 1994). In 1975, UN'S Women's year, the UN concentrated on research on Women in Development (Boserup, 1970) (i.e. status and politics of women in development) which sampled various geographies, castes and ethnicities of women and the women's participation/knowledge of women's' rights and development issues. This was published under 'The Status of Women in Nepal' (CEDA, Tribhuban University) from 1979 to 1981 . However, some of the earlier movements have arguably lacked participation and inclusion of women outside Kathmandu, in terms of geography, social status, ethnicity and caste, and primarily focused on approaches to development by state and donor agencies (Tamang, 2009; Leve, 2007). Social diversity did not become part of the feminist
} 
development, strongly supported by the state and foreign aid. ${ }^{2}$ Like most women's movements, it aimed to achieve a singular target of providing agency and rights to women ('all' Nepali women) such as citizenship, education, health, labour and so forth. From its beginning though, it has been layered with sometimes conflicting political, social and cultural ideologies. These sought to construct a homogenised 'Nepali woman' for all Nepali women, suggesting that all Nepalese women suffered from the same gendered issues and needs. Sierra Tamang (2009) and Lauren Leve (2007) have argued that mainstream feminism in Nepal has been and is a 'privileged' movement that circulates in restricted spaces, with restricted political and donor driven agendas - which omit the diversity of ethnic, caste and class identities of women in Nepal.

The Nepali feminist movement has been subjected to much criticism regarding its role, whom it accommodates and caters to and whether is it truly for all Nepali women or exclusively for the urban and elite. Tamang (2009) and Leve (2007) have pointed out that there is a considerable gap between what is represented by feminists in the cities or in positions of power to what is actually required to address issues of the different geo-ethnic and rural necessities. This, they argue, deprives Nepali women of a functioning rights mechanism:

Contemporary misrepresentation of 'the Nepali woman' as a single over-arching category in the socioeconomic sphere of development (which has been achieved at the expense of consistently effacing manifest difference), with the desire for a generic Nepali women who shares a common set of needs and values with all her fellow female citizens, has produced not merely a homogenized Nepali woman, but, perhaps more importantly, one who is systematically denied agency (Tamang, 2009: 66).

\section{WOMEN AND COMICS}

So, where are women and comics located in terms of Nepali feminism? Comics, like art, serve as a form of social commentary in that they reflect the times in which they are created (Merino, 2001). They also act as new cultural artefacts that can be read and studied. Rather than to begin with a feminist idea, this essay examines what Nepali women comic artists have chosen to showcase in their personal narratives. Women comic artists only began drawing comics towards the late 1990s in Nepal, and there is limited to no archival material to collect and analyse from. ${ }^{3}$ The images collected in this essay show examples of the diverse visual forms and storytelling methods of various women artists in Nepal, and much of the analysis is based on interviews with the artists.

The modern comic format used by Nepali artists appeared towards the 1960s with the privatisation and expansion of printing presses. It has flourished since and become a regular part of national dailies such as Gorkhaptra, The Kathmandu Post, Kantipur and The Himalayan Times. The appearances of comics in the 1960s were limited as there were not many platforms for expression, other than political expression. Most comics appeared in newspapers and national dailies, thus limiting them to being political in nature or in children's magazines. ${ }^{4}$ Women were depicted as epitomes of perfection, 'Sati-Savitri' 5 , religious figures or part of folklore and, in some instances, as villains or objectified subjects that are part of a larger political satire. ${ }^{6}$

Towards the late 1990s, and more so in the beginning of the 2000s, female artists started appearing, but sparsely. According to an interview of Shushma Rajbhandari and Sangee Shrestha by Fungma Fudong (cited in Lent, 2015), the option for women cartoonists was a problematic choice between domestic life that was bound by socio-cultural obligations and obstructions or freedom of expression with consequences of an opinionated traditional society

discourse until the 2000s. I use the term 'essentially' to highlight the fact that research and socio-political debate regarding the Nepali feminist movement began highlighting the gaps of social, cultural and geographical exclusion of women (Leve, 2007; Tamang, 2009; further reading Acharya, 1994; Upadhya, 1996).

${ }^{2}$ Nepal was trying to create a single national story and identity after the fall of the oligarchy in the 1950s. Thus, it sought to homogenise its heterogeneous cultures (Gellner et al., 1997; Whelpton, 2005): 'Catalyzed by the 1975 UN International Women's Year, foreign donors channeled funds into "developing" an essentialized "Nepali woman" in accordance with women in development (WID) doctrine dominant in the global development sphere' (Tamang, 2009: 65).

${ }^{3}$ Much of the material collected and analysed for this article was from personal archives, as libraries and institutional archives are not as well maintained, inaccessible or non-existent.

${ }^{4}$ Lent (2015): Sequential art has been part of Nepal's historic and traditional art forms such as Bilampos, narrative manuscript paintings or patta paintings. In these, the female is often depicted as of mythical nature, a mother goddess or deity, or part of the worshiping patron panel. (Further reading: Pal (1974); Bajracharya, 2016; Chitrakar, 2012; Chitrakar, 2017.)

${ }^{5}$ Sati-Savitri is a goddess in Hindu mythology, Savitri being daughter of a solar deity and wife of god Brahma and Sati 'good woman/chaste wife'. In combination, the terminology means a woman who is defined as the epitome of the faithful wife and paragon of virtue or a woman of virtue in general. In modern literature, art and linguistic uses it has a negative connotation (Bhatt, 2013: 130; Wildermuth, 2009; further understanding of the term in contemporary language can be found in academic literature on Indian Cinema). It is similar in meaning to the dichotomy of the Victorian ideal woman vs. the fallen woman (Anderson, 1993; Kühl, 2016).

${ }^{6}$ This observation is based on interviews with all artists for this paper, as well as on the survey of Nepali comics as a whole. 
(Lent, 2015). Comics artists such as Preena Shrestha and Kanchan Burathoki, though from a generation younger, have stated similar experiences, where socially, culturally and in the working sphere, women cartoonists are not taken seriously enough and making comics as women seen as hobby rather than a profession. ${ }^{7}$

\section{METHODOLOGY}

For this article, I have interviewed several prominent female comics artists - Bandana Tulachan, Kanchan Burathoki, Kripa Joshi, Preena Shrestha, Shraddha Shrestha and Sangee Shrestha. I have looked and analysed their body of works that are found in their personal collections, in print and on social media such as WordPress, Instagram and Facebook. I also had group discussions with the artists, and prepared a questionnaire for the artists to respond to.

In addition, I have interviewed several Nepali editors of publishing houses and dailies, and studied their body of works for comparison and understanding of where the women and their comics are located in the context to the comics scene of Nepal as well as the Nepali feminist debate. Due to lack of literature on Nepalese comics artists and art as a whole (outside of traditional and historical art contexts), I have collected and read through international theoretical literature relating to comics, and analysed how these fit into the context of Nepal.

\section{SATIRE AS COUNTER CULTURE}

Sangee Shrestha worked as a political caricaturist between 2002 and 2003 for Kamana Gaijatra magazine. She used humour and satire to address Nepal's socio-cultural perception and treatment of women. She was ridiculing both society's gaze and her male counterparts who largely relegated women in their cartoons to the background, as either well-meaning, curious fools or nagging wives, thus confronting dominant images and perspectives of patriarchy.

In Figure 1,8 Shrestha indicates that the woman in the comic is not just a mother and housekeeper but also a labourer for her offspring. Shrestha is reflecting a social norm in Nepal (though exaggerated). She felt that women like herself, not just as a woman but also as a cartoonist, faced a problematic choice between domestic life that was bound by socio-cultural obligations and obstructions of freedom of expression with consequences of an opinionated traditional society (Lent, 2015; S. Shrestha, Personal interview, 2019, July 24).

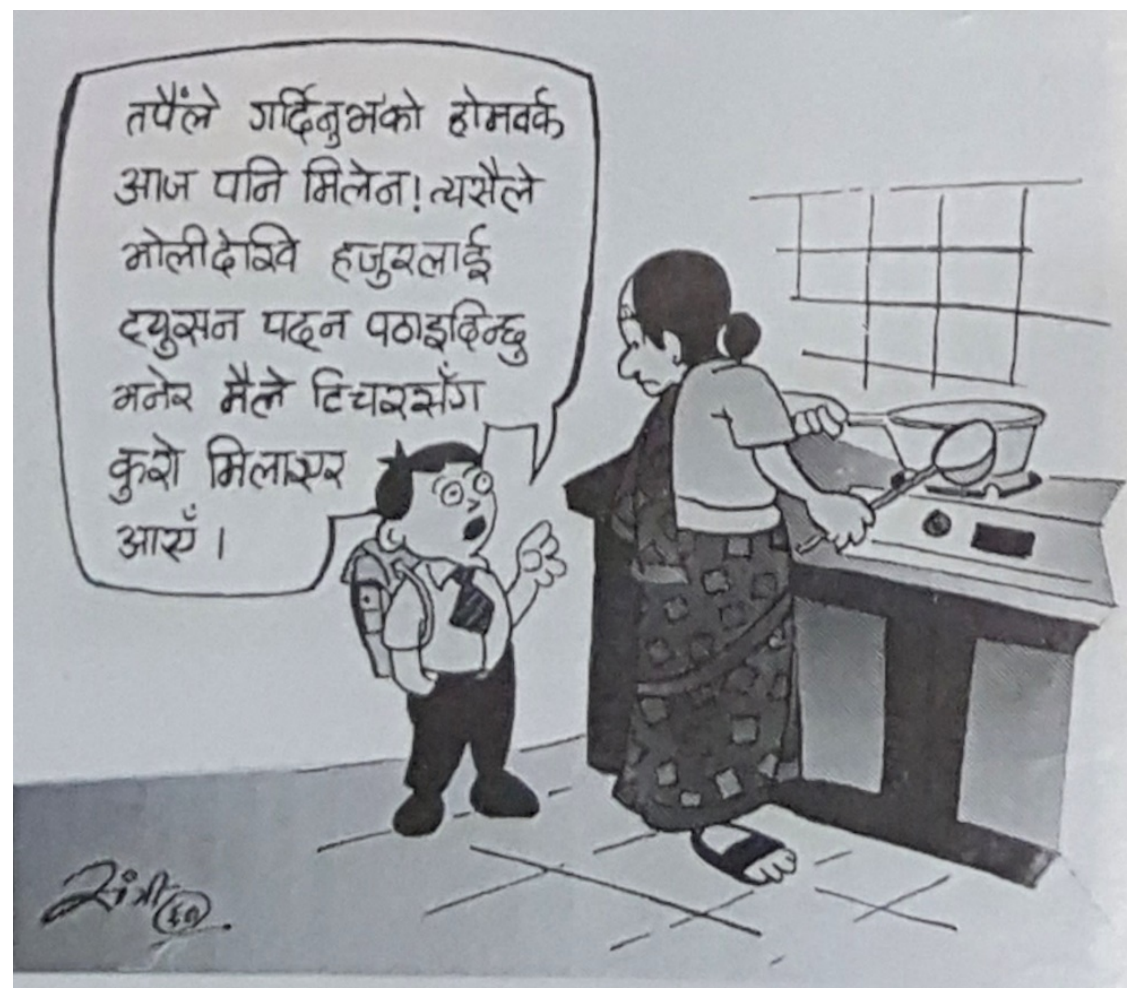

Figure 1. Untitled 1. Sangee Shrestha (2003). C Sangee Shrestha.

\footnotetext{
${ }^{7}$ Interview with Preena Shrestha (2019) and Kanchan Burathoki (2019).

${ }^{8}$ Approximate translation: boy character: 'you again did my homework wrong. From tomorrow you will be going for tuition, I have already arranged it with my teacher'
}

(C) 2020 by Author/s 


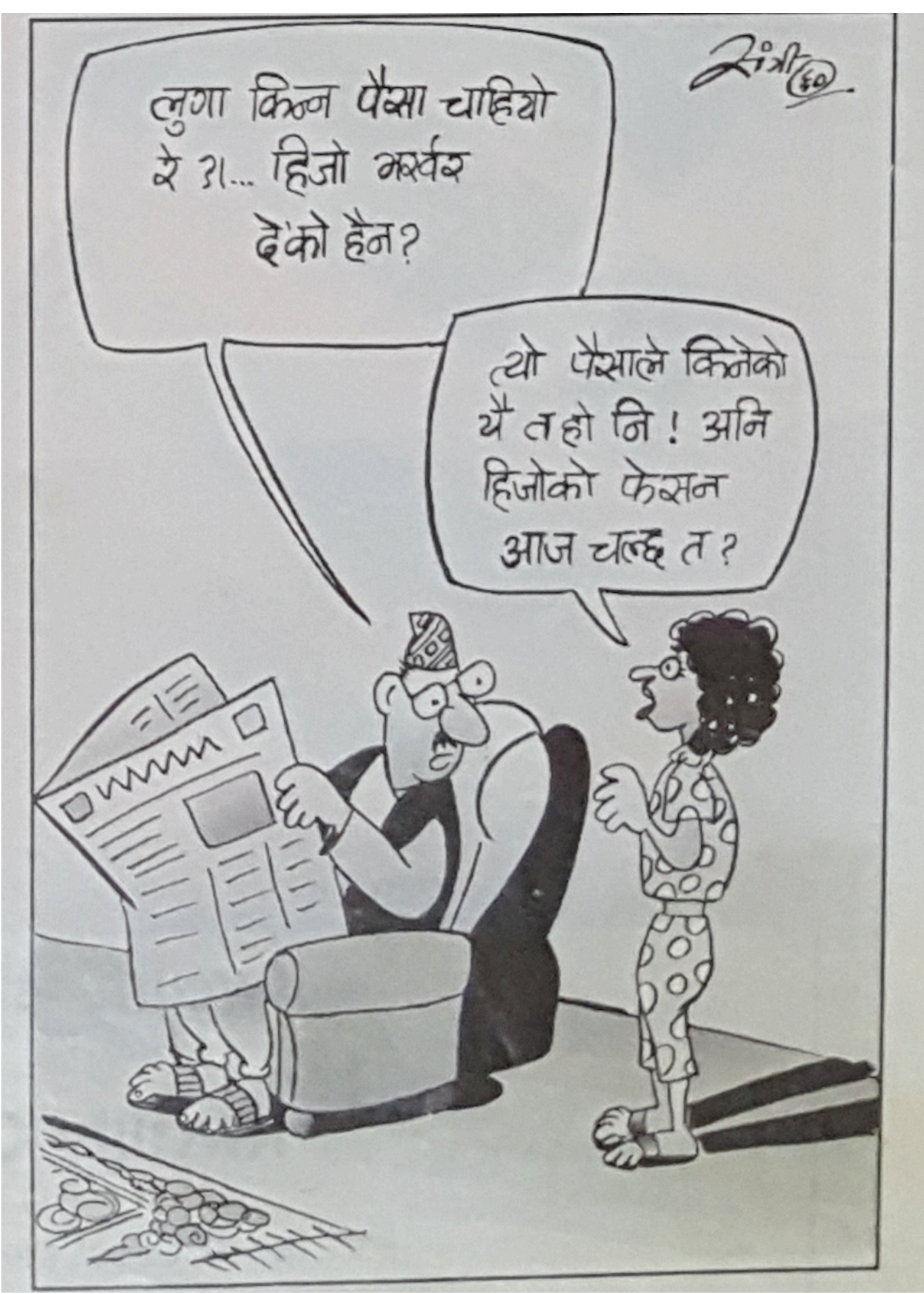

Figure 2. Untitled 2. Sangee Shrestha (2003). C) Sangee Shrestha.

In Figure 2, ${ }^{9}$ Shrestha has created a stereotype of the frivolous woman figure who is obsessed with fashion trends. The man of the household (this can be interpreted from the image in terms of size, and the fact that she is asking him for money) cannot understand why she needs more clothes. Figure 3,10 Shrestha as an artist, has created a pun at self-representation, where she is asked what she is trying to say with her body of work. This could be interpreted as Shrestha using juxtaposition in the relative sizes of characters in both Figures 1 and 2 to indicate the smaller characters to be clichéd social stereotype of women that are opinionated, inquisitive, troublesome and silly.

\footnotetext{
${ }^{9}$ Approximate translation: male character: What are you trying to show with this painting?'; female artists: 'Please be patient. Let me finish the painting and you will see'.

${ }_{10}$ Approximate translation: male character: 'You need money for clothes again? Did you not just buy some yesterday?', woman character 'Yes, I am wearing them now. But that was yesterday's fashion.'
} 


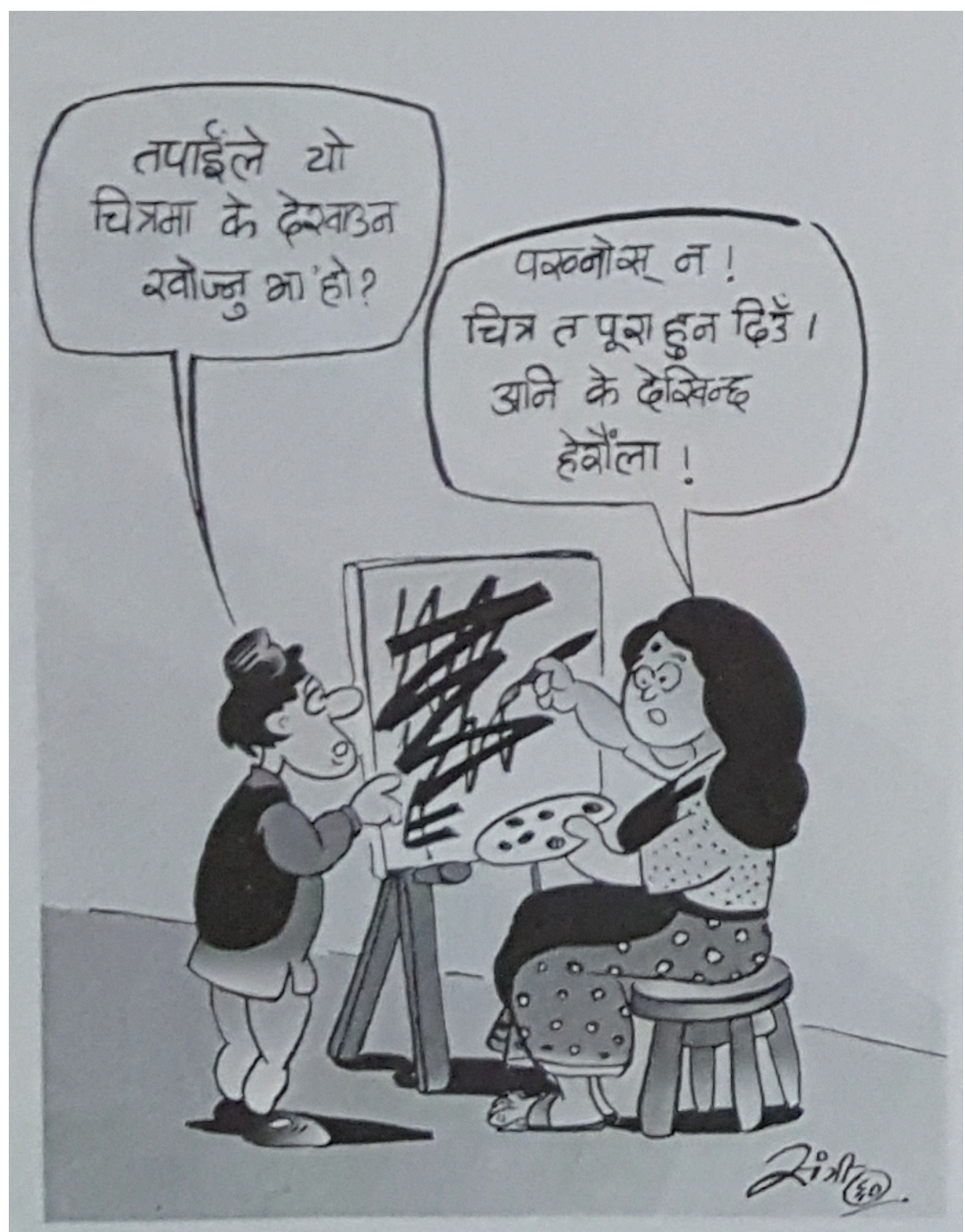

Figure 3. Untitled 3. Sangee Shrestha (2003). (C) Sangee Shrestha.

Artists who followed after Sangee Shrestha provided more personal narratives that disclosed glimpses of their lives and emotions, rather than socio-cultural and political attitudes.

\section{BODY IMAGE}

Miss Moti and the Big Apple (Joshi, 2007) was self-published as part of Kripa Joshi's MFA thesis. The central character was inspired by Joshi's own lack of body confidence. Her idea was to create a body positive character that was full of life, mirroring herself and her mother's character. Both she and her mother are big women, who are self-sufficient and independent thinkers.

'Moti' has a dual connotation in Nepali, meaning a 'pearl' as well as 'fat'. Joshi has cleverly used the name for both its meaning - a hidden gem in a negative connotation of body image. She uses the same play on the word 'Moti' with image in her first 2 comic covers (Figure 4) which conjures the image of 'The Birth of Venus' by Botticelli, with Moti as a goddess of ingenuity. 


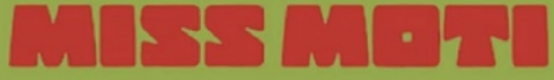

AND THE

Big Apple

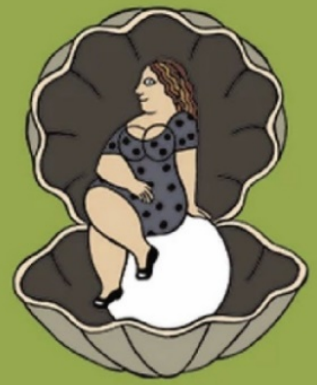

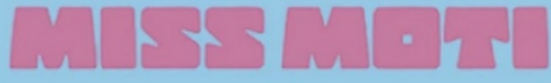

AND

Ciotton Ciandy

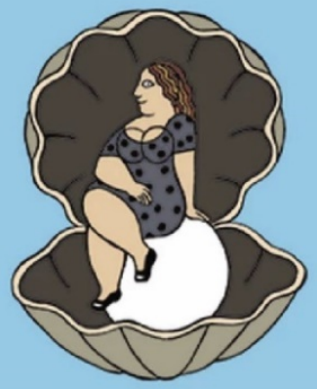

BY KrIPA Joshi

BY KrIPA Joshi

Figure 4. Covers of Miss Moti and the Big Apple (2007) and Miss Moti and Cotton Candy (2007). Kripa Joshi. 2012. (C) Kripa Joshi.

In her work, Joshi is portraying her self-image through the comic in a playful manner, as curvy and vivacious. By drawing and publishing her comics she is confronting her own anxieties about her body image and at the same time enjoying the process of creating herself. Through her work, Joshi deconstructs Nepali notions of body ideals and individual attitudes towards oneself.

In Figure 5, Miss Moti and the Big Apple (2007), for instance, her character is coyly flirting as 'Eve' with 'Adam' ignoring her beauty over a juicy red apple. The nudity here is not overtly sexual, but at the same time in juxtaposition to the cello is indicative of Joshi comparing herself to an idealised design of her own body as beautiful.
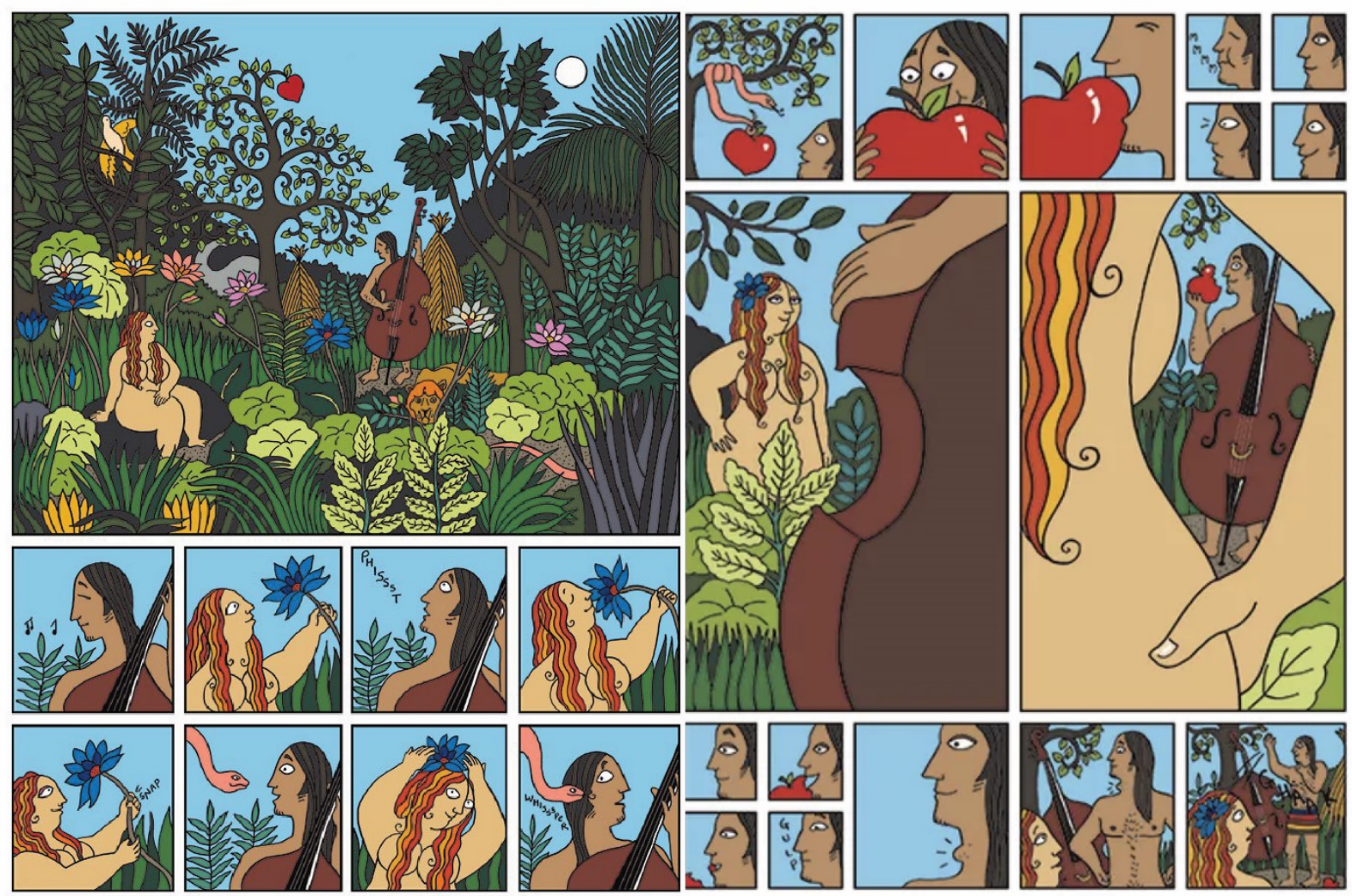

Figure 5. Excerpt from Miss Moti and the Big Apple. Kripa Joshi. 2007. (C) Kripa Joshi. 
In Figure 6, 'Burn bleed boom' (2017), a self published zine, Shraddha Shrestha depicts a graphic break up. It is raw and honest in its imagery of pain inflicted and wishful vengeance upon the 'ex'. In Figure 7, 'The permission game' (2019), she invites the reader into a visual game of seeking permission, which ends either in frustration and masturbation leading to sexual gratification.
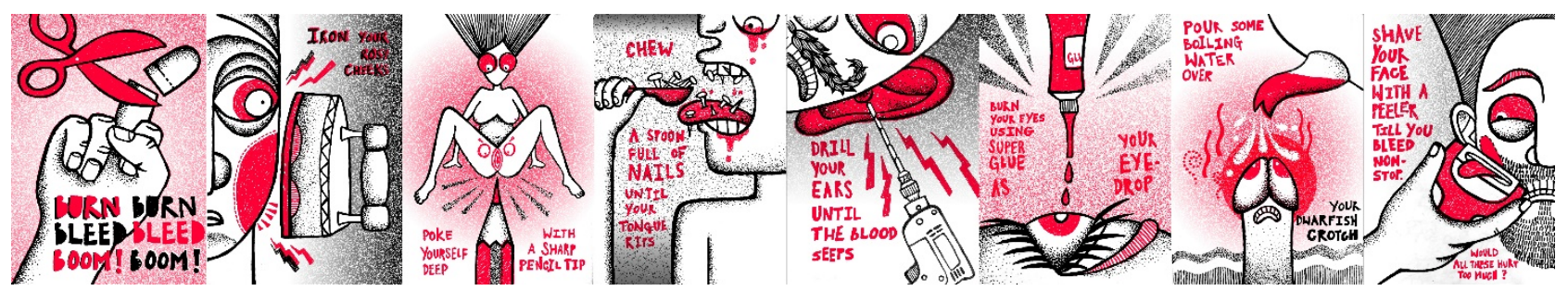

Figure 6. 'Burn bleed boom'. Shraddha Shrestha. 2017. (C) Shraddha Shrestha.
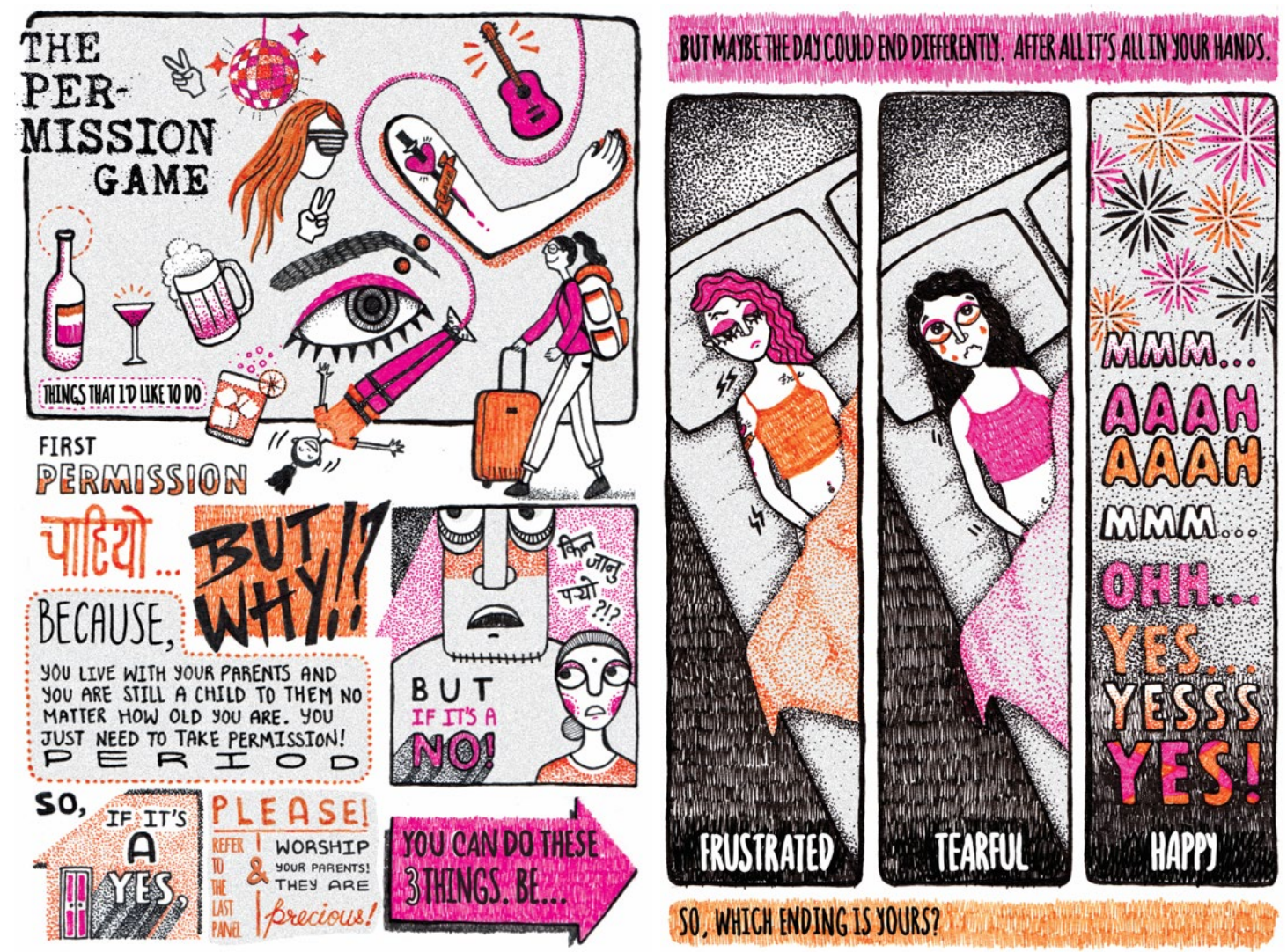

SO, WHICH ENDING IS YOURS?

Figure 7. 'The permission game'. Shraddha Shrestha. 2019. (C) Shraddha Shrestha.

In both her comics, Shrestha does not shy away from expressing her sexuality or private relationships, which within the Nepali social sphere continues to be a subject of taboo. It is an open secret that people date, and that as unmarried adults in a relationship they are sexually active. As such, it is a socially accepted norm not to be spoken of in public, yet Shrestha candidly challenges this social taboo with her vivid imagery. Shrestha reflects in a sense a radical woman who is not scared to be openly vulnerable and confident at the same time. She can be seen as a nonconformist, in context of Nepali culture, for her progressiveness in portraying her desires and risqué can do attitude.

But why do these women artists choose illustrate their autobiographical accounts instead of imagined ones? Woman-drawn comics allow for dialogue on gender-related issues. They address problems of conformity to social norms and ideals, objectification and oppression of individuality and rights. Autobiographical work such as these, afford the comic artist creative licence. As Chute (2010: 2) elaborates, autobiographical work allows artists to:

Return to events to literally review them...they productively point to the female subject as both an object of looking and a creator of looking and sight...they provoke us to think about how women, as both looking and looked at subjects, are situated in particular times, spaces, and histories. 
In Kripa Joshi's and Shraddha Shrestha's comics, the authors have taken a comfortable position in self expressions of both body as an object of anxiety and sexuality/driven by desires. They show readers how they view themselves and offer themselves openly to the reader's gaze and scrutiny.

\section{REAL LIFE, REAL ISSUES}

Both Preena Shrestha and Kanchan Burathoki give semi-autobiographical narratives that echo similarity and are reflective of works like Alison Bechdel's Fun Home (2006), and Marjane Satrapi’s Persepolis (2003).
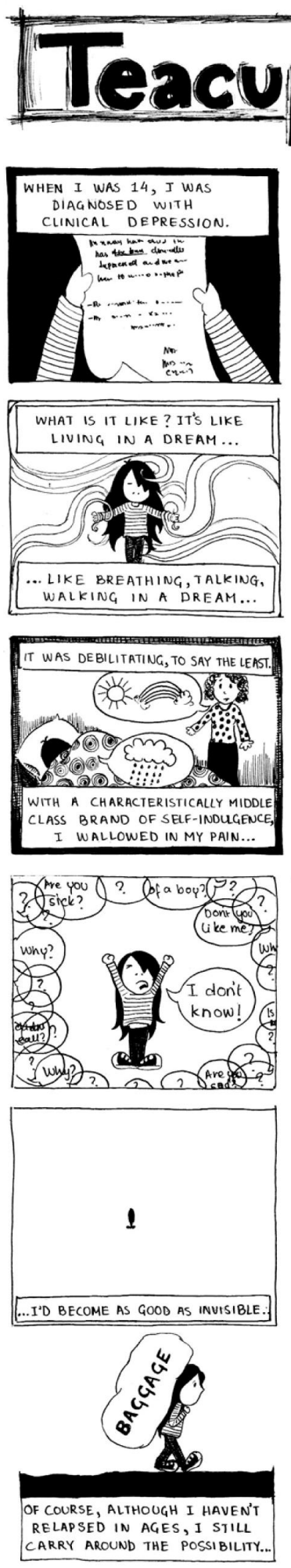
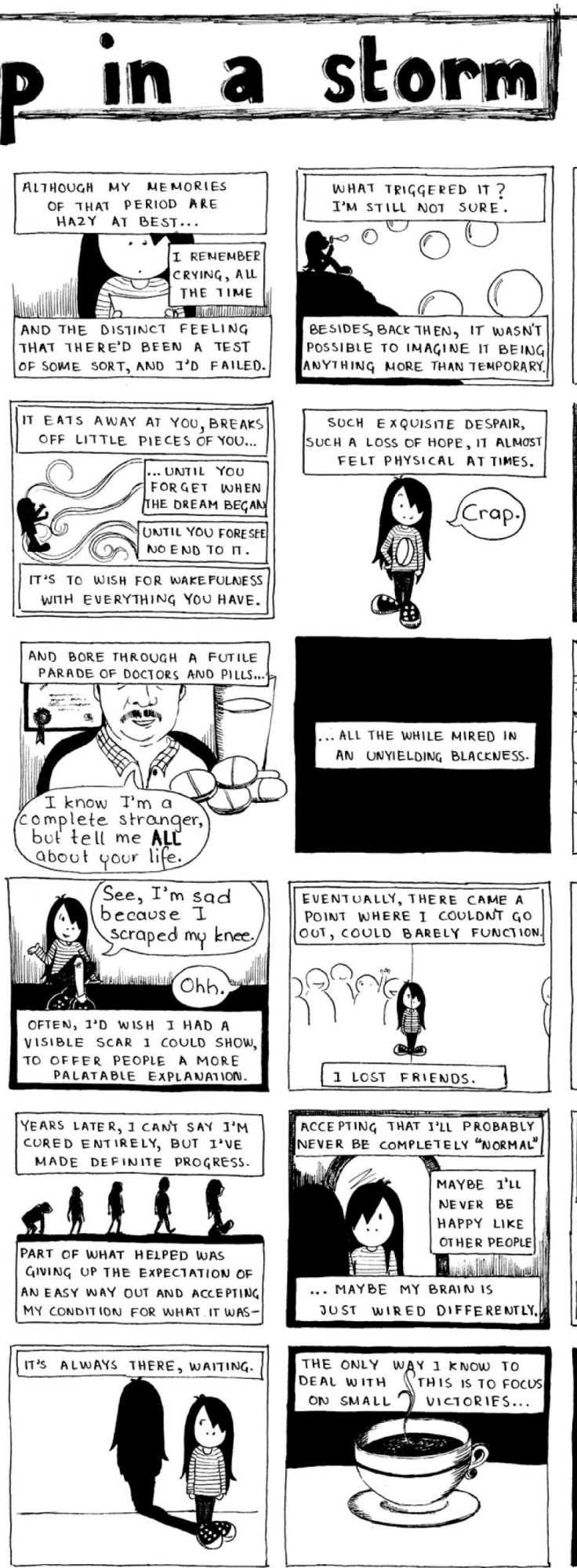

PREENA SHRESTHA
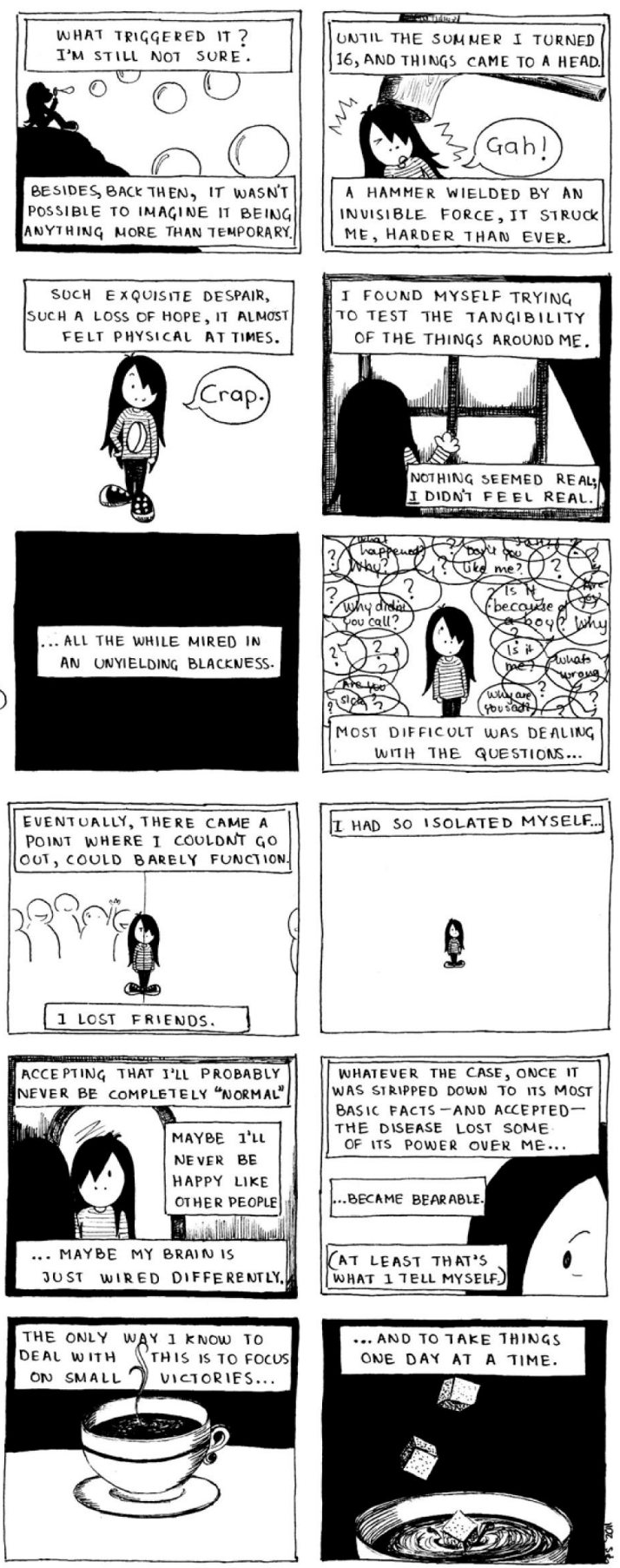

Figure 8. ‘Tea cup in a storm’. Preena Shrestha. 2011. (C) Preena Shrestha. 
In Figure 8, Preena Shrestha's thought-provoking work, 'Tea cup in a storm' (2011), explores her life and longterm depression, social anxieties and the turmoil of emotions that came with it. The subject of depression is surrounded with stigma in Nepal and is still a topic of taboo (as it is to speak about other mental health issues). The comic format is the medium which in her own words and images allowed her to find a constructive form of therapy and also encouraged her readers to engage with the subject of mental health.

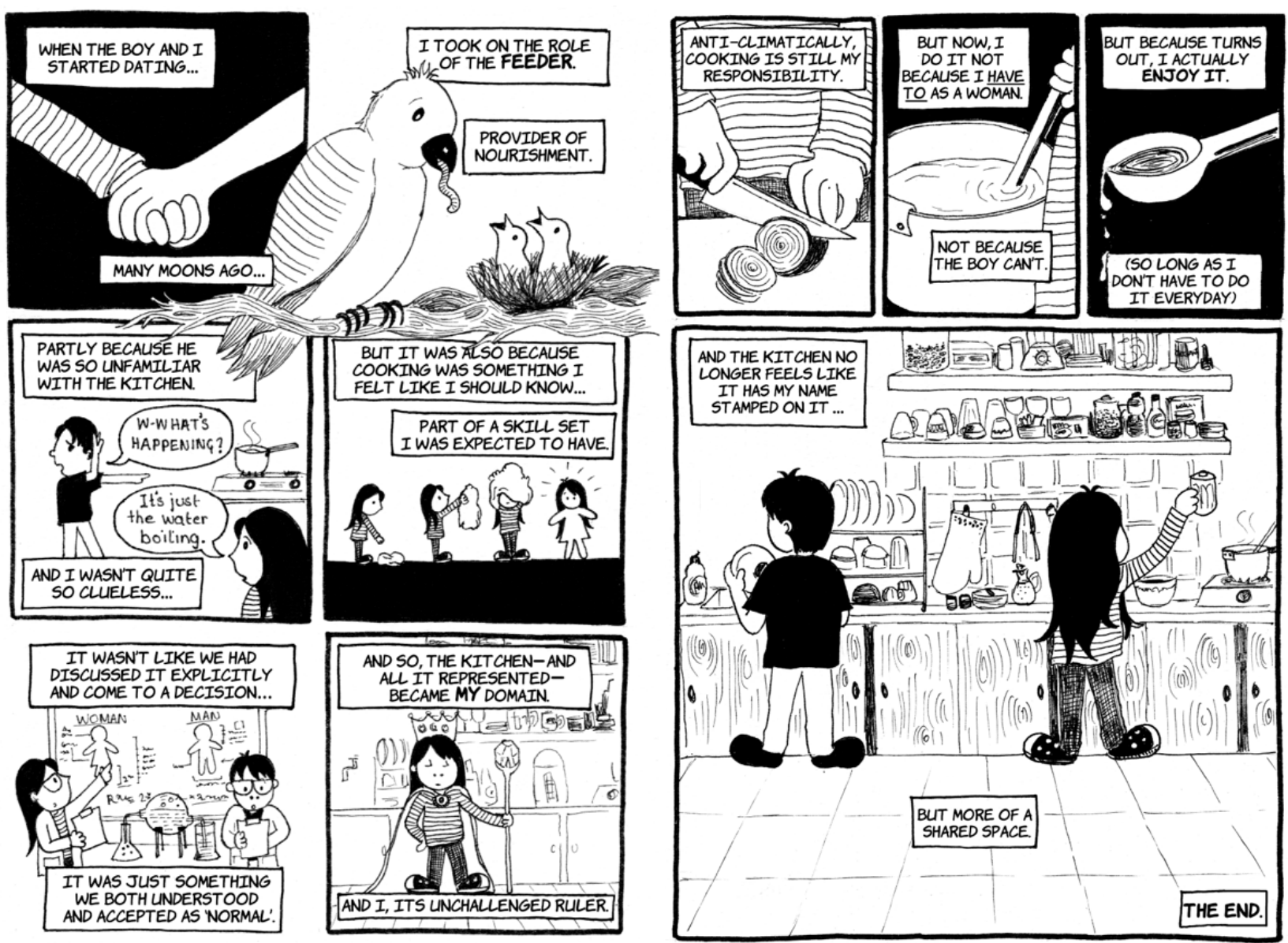

Figure 9. 'Bhanchaghar'. Preena Shrestha. In press. (C) Preena Shrestha.

In her next comic, 'Bhanchaghar' (in press), shown in Figure 9, Shrestha tackles the cultural issue of domesticity and the gender roles that are prescribed in the traditional institution of marriage. She comically describes how she 'chose' to take on the role of domesticated woman/wife, which had been ingrained into her by generations of women. Like her previous comic, she comes to terms with the fact that she cannot fit into the socially-assembled gender role that most Nepali women are assigned to. In her seriousness, Shrestha uses humour through her character who is too little for her big shoes.

The role of women, in the above mentioned comics, come from the position of the daughter, the mother, the spouse/partner and the social image of a woman which carry a tone of wry ambivalence towards their gender roles.

Both Preena Shrestha and Kripa Joshi use tamer forms of self expression, that are safe and appear to be created guardedly against any criticism that could arise from their visual narratives. They do not provoke a dialogue that debates the circumstances of middle class women in Nepal, but rather reiterate through their creativity their positions as part of these women and their class struggles. Shraddha Shrestha on the other hand rebels against it, and is edgier in her questioning and critique of a woman's role and opinions. 


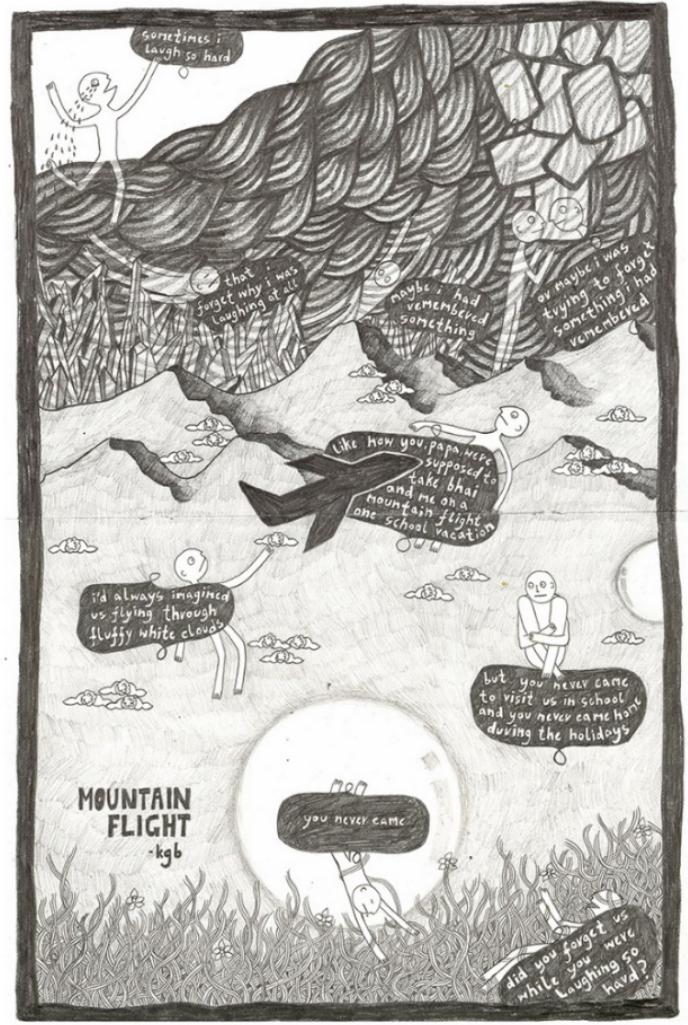

Figure 10. 'Mountain flight'. Kanchan Burathoki. 2013. (C) Kanchan Burathoki.

Kanchan Burathoki uses the comic medium to combine her poetry with visual images. Two pieces of her selfpublished work, Figure 10, 'Mountain flight' (2013) and Figure 11, 'Breath in breath out' (2019), are very personal journeys of trauma, which Burathoki expresses in two different formats. In Figure 10, 'Mountain flight', Burathoki writes a poem into a single image format, which is playfully illustrated. This was in memory of her father. On the other hand, in Figure 11, 'Breath in breath out', she shows a more sombre tone in narrating how she dealt with the passing of her mother, from struggling, to finding some form of semblance and coming to terms with the fact.
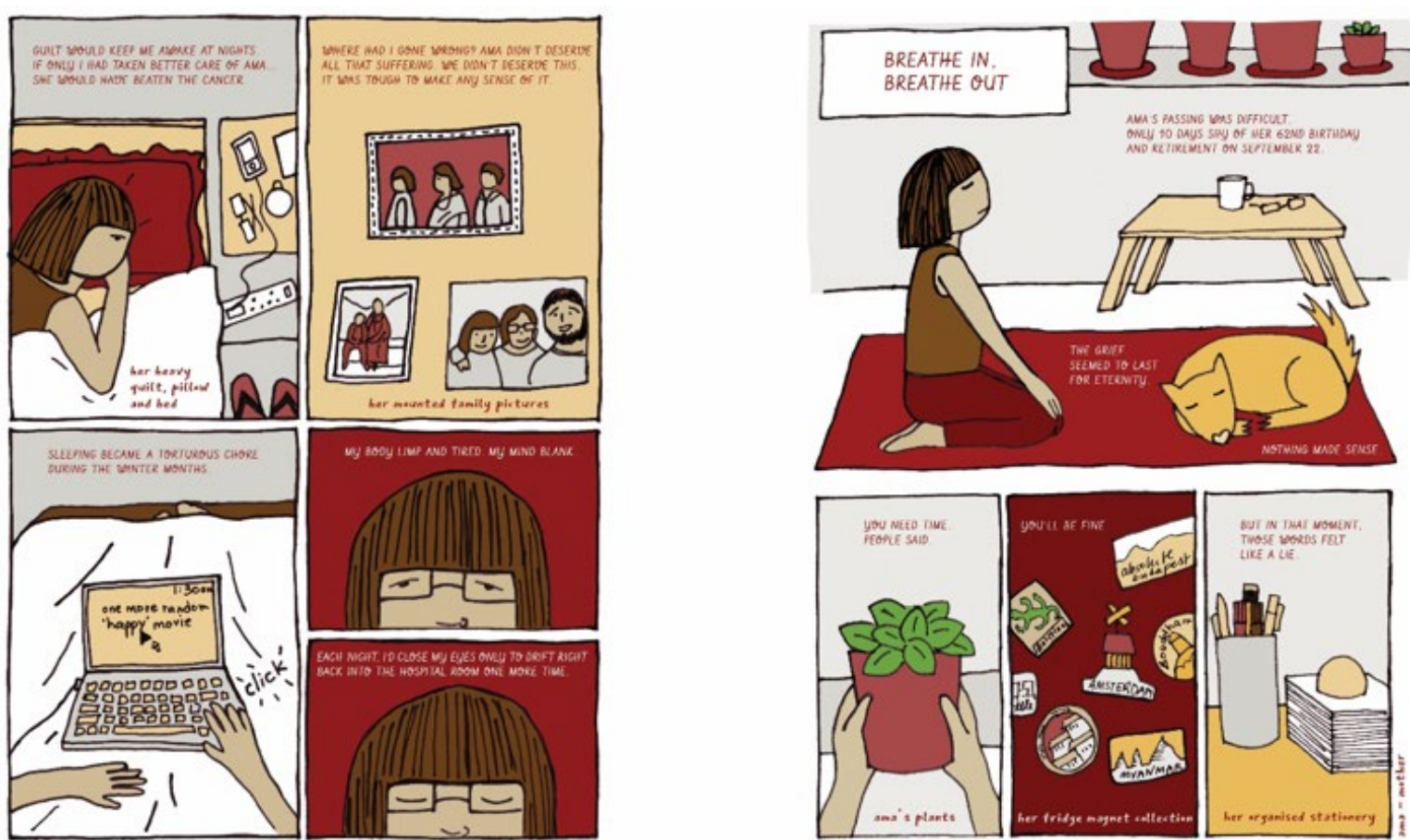

Figure 11. 'Breath in breath out'. Kanchan Burathoki. 2019. (C) Kanchan Burathoki. 
Chute (2010, 2017) and Dean-Ruzicka (2013) have discussed how comics and graphic novels of autobiographical nature allow the reader detailed insight into the author's life. Chute (2010) adds that through this medium, 'Authors revisit their past, retrace events, and literally repicture them' (2010: 2). These are based on memories, histories, encounters and events experienced by the author/artist, which are depicted through the filtered lens of factual [re]imagination. They '...let the reader look at both the subjectivity of the narrator and the cultural forces that have shaped them' (Dean-Ruzicka, 2013: n.p.).

The biopic style comics by Preena Shrestha, Shraddha Shrestha, Kanchan Burathoki and Kripa Joshi are based on their real lives, real experiences and individuality. Their stories become human and relatable. These comics are narratives of self discovery, through memory, experience and self-expression.

\section{METAPHORS}

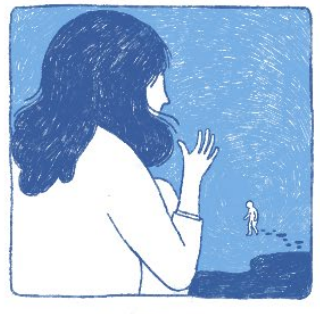

SOMETIMES

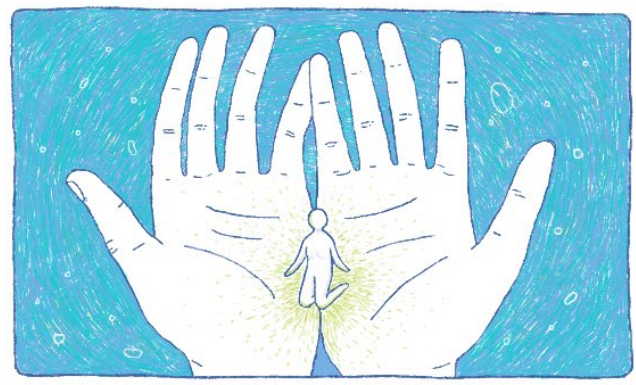

TO FEEL.

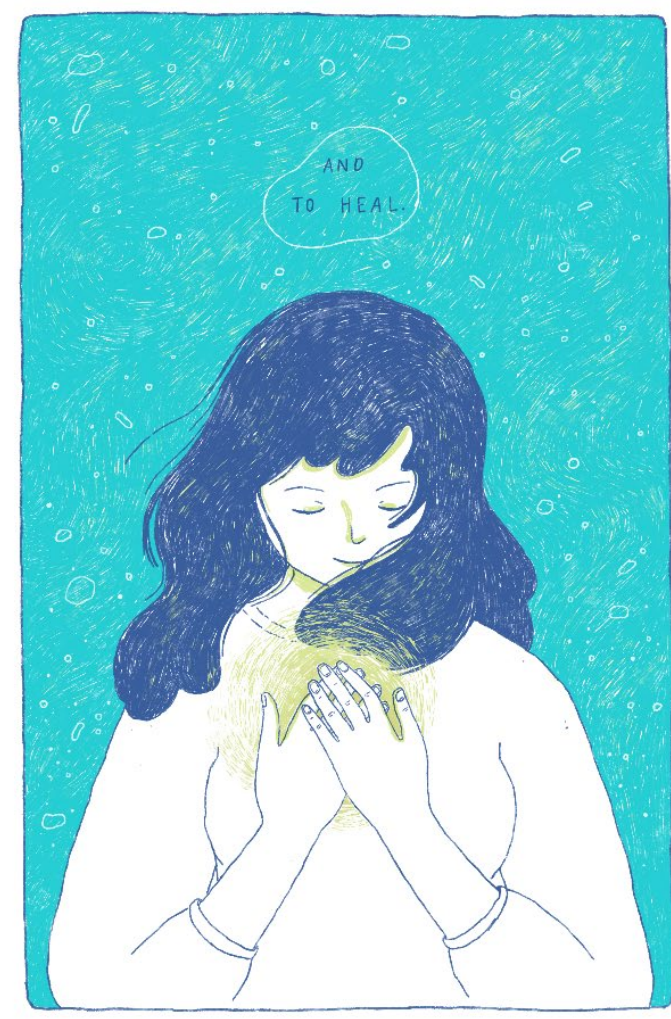

Figure 12. 'To love'. Bandana Tulachan. 2019. (C) Bandana Tulachan.

Bandana Tulachan uses a figurative expression in her story-telling technique and visual process. In Figure 12, 'To love' (2019), she employs fluidity and imagination to express the courage of accepting that 'low' feelings and hopelessness, and finding ones feet through encouragement and/ or asking for help. Many times, like in Preena Shrestha's 'Tea cup in a storm' comic, mental and emotional issues are not openly expressed, and asking for support is limited through social constructs of what is appropriate and what is not. Through her comic, Bandana Tulachan encourages the reader to find a helping hand rather than suppress it.

Similarly, in Figure 13, 'Self love', I, Promina Shrestha, employ wordless comics to tell a metaphorical story of finding self love, and learning to cultivate and nurture the self. The comic allowed me to show that, as an individual, one could embrace oneself without the validation of others, especially so as a woman. As women navigating a patriarchal social structure daily, our identities and desires habitually become subverted with social and cultural obligations and expectations. Nicola Streeten (in her Foreword for Self Love, 2019) remarked on that in Nepal the perspective of self love does not come from a place of individualism and gendered indulgence, but rather a place of family, friends and the everyday, which is firmly contextualised within the artists cultural positions. 

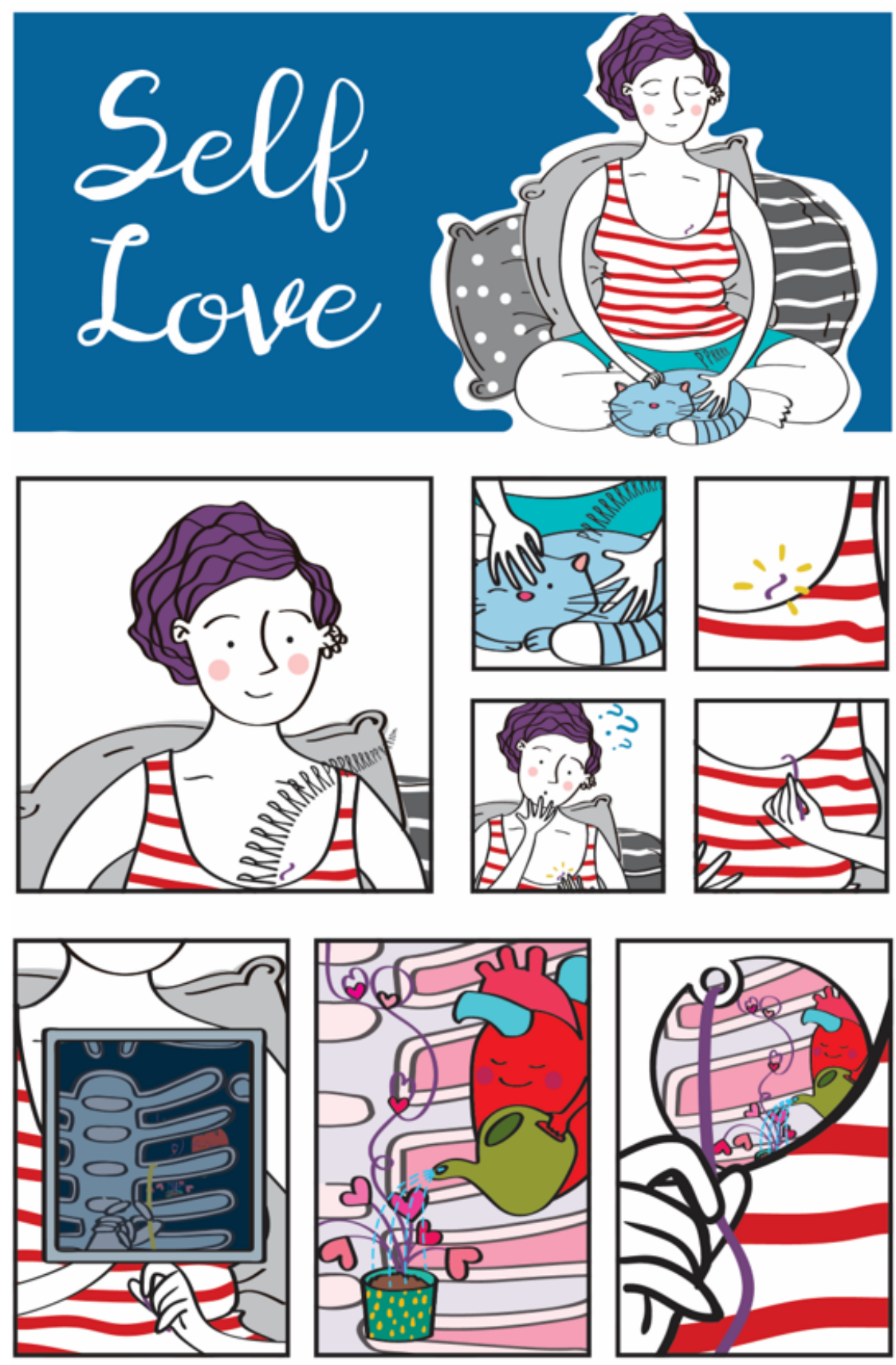

Figure 13. 'Self love'. Promina Shrestha. 2019. C Promina Shrestha.

In this collection of comics illustrated in this essay, the women comic artists, including myself, are using the comic medium as a tool for self expression. In a society like Nepal, the defined gender role of women can be restrictive. Comics provide an ideal getaway to defy these conformities. They allow us to confront the overemphasised expectations of women by Nepali society that we have been brought up in.

\section{ON THE FUNNY SIDE}

Figure 14, 'Period' (2018), and Figure 15, 'Bad hair day' (2009), by Shraddha Shrestha and Preena Shrestha, respectively, address everyday women's issues of biology and vanity through a sense of humour, in single panel comics. Sometimes things in life just cannot be helped, such as having uncontrollable hair that will not stay put or forgetting it is that time of your month when one is having a great day out, and as artists, looking back at these events adds to comical life anecdotes. 


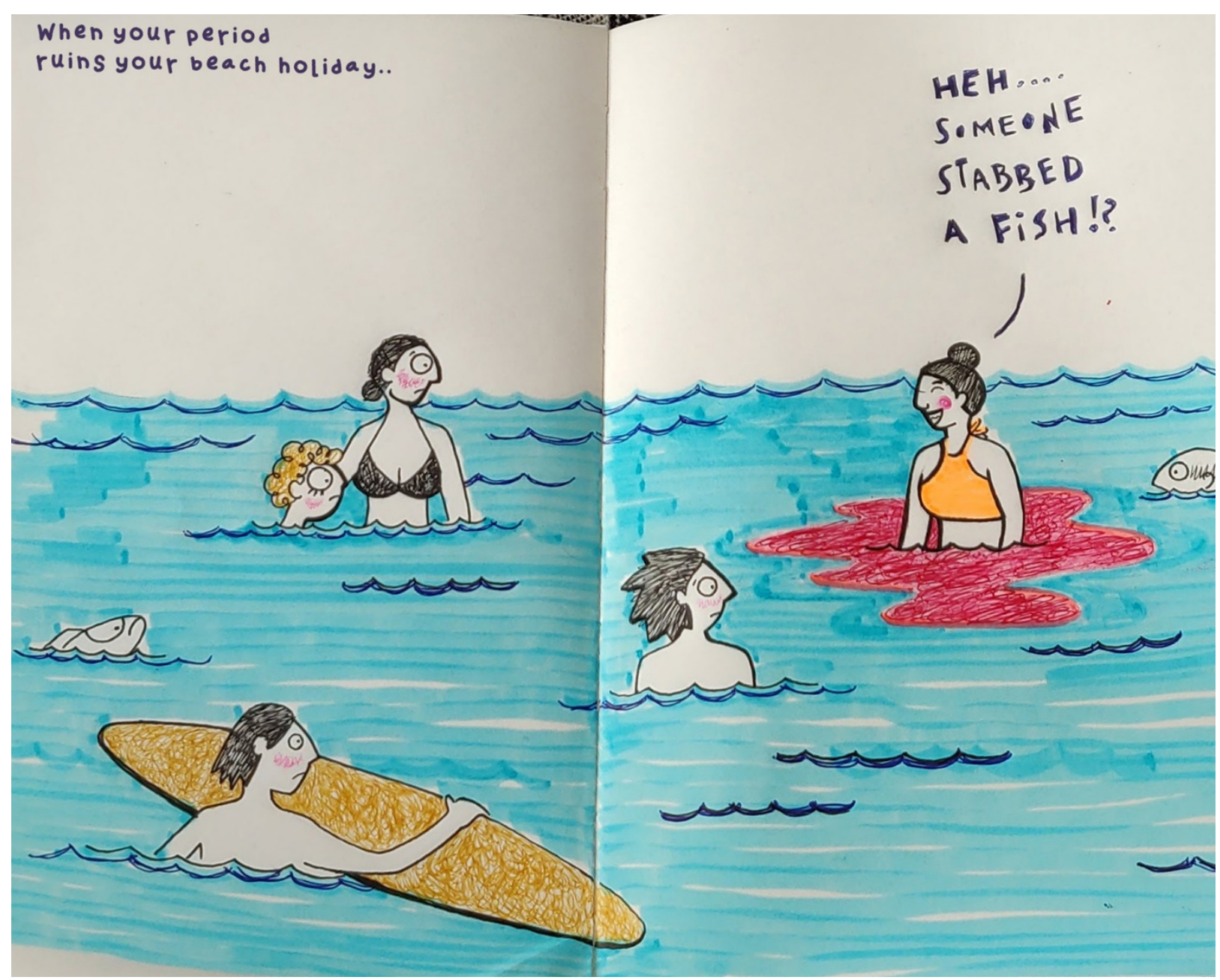

Figure 14. 'Period'. Shraddha Shrestha. 2018. C Shraddha Shrestha.

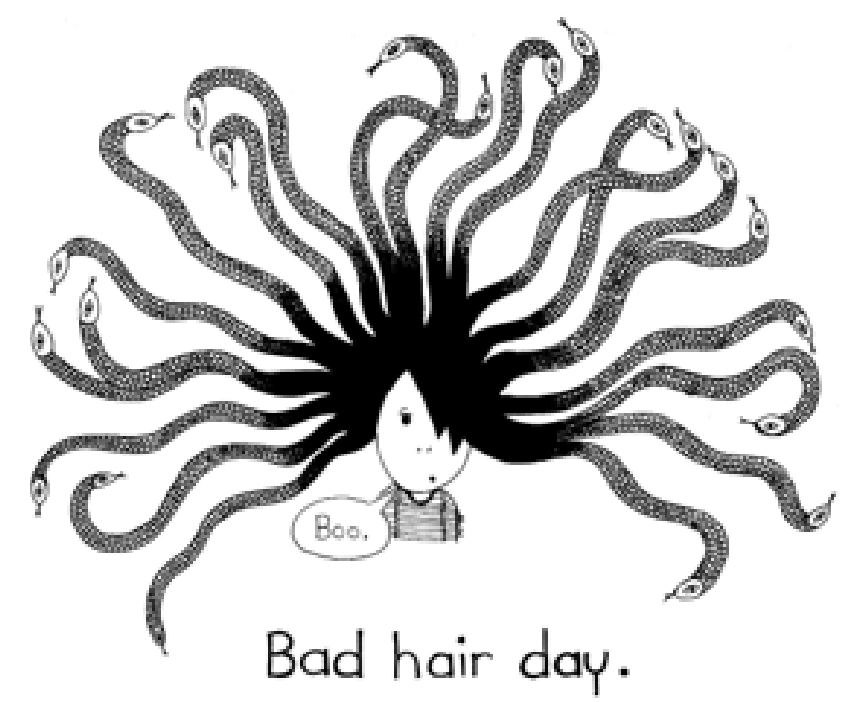

Figure 15. 'Bad hair day'. Preena Shrestha. 2009. (C) Preena Shrestha.

In Figure 16, Promina Shrestha's 'Are we there yet?' (2018), three different women characters are representative of my own self images (in terms of temperament, attitude, body image and sexuality). Though meant in jest, and shown as a small trekking expedition, the characters are illustrative of my own navigation within society. 


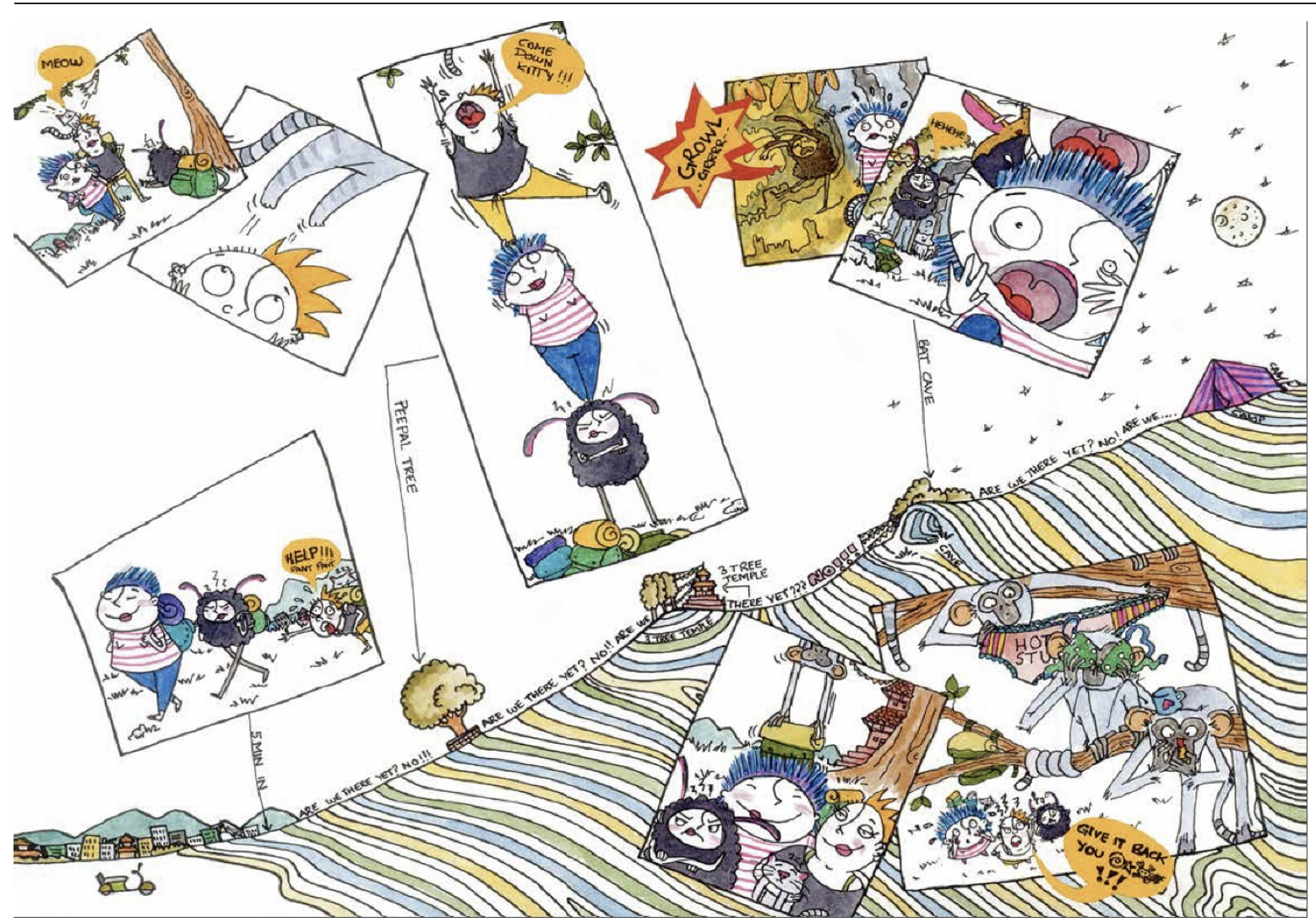

Figure 16. 'Are we there yet?'. Promina Shrestha. 2018. (C) Promina Shrestha.

\section{DISCUSSION}

At a glance, these comics do not advocate the larger Nepali feminist movement which aims to give agency to women in terms of rights to citizenship, education, health, labour and so forth but also to incorporate the individual struggles of ethnicity, caste and class within women's rights in Nepal. There is a clear emotional and political disconnect between the private spheres of the artists and that of the larger debate. The comics are not fully representative of class, caste and ethnic representation of Nepal and Nepali women. And yet, by inking their lives, experiences, emotions and thoughts and publishing them on social media sites such as Instagram, they are contributing to the effort through a visual personalised narrative that can be located within the larger global comic feminism and activism.

It is crucial to understand that Nepal's comic scene is a highly gendered space. Political and satirical cartooning is a dominant genre in Nepal, which has been asserted by male artists as their area of expertise. While the narratives illustrated by women occupy a marginal position, depicting the domestic, personal experiences and stories of the single woman. This, in turn, has had a deeper implication within Nepali culture. Political satire is seen as more intellectual than the individual's commentary on personal life, which is perceived as a whimsical or frivolous activity by women (a 'low brow' genre).

Nepali women artists are not afforded as much recognition and visibility as their men counterparts. Although the Nepali comic scene started half a century ago, there is still a prejudiced limitation of accessibility for women, particularly in print media. The internet has been the most available platform for most artists in this regard, which has also supported a shift in readership and demand for this medium.

In my reflection of the collection of comics in this essay, it is disputable whether these comics can or should be characterised as 'feminist'. The artists themselves are not motivated first and foremost by an avowed sense of feminism or activist purpose; rather, their work puts forward the reality of their experiences. The artists and their drawn characters have come in varied shapes and sizes, and are constructs of women's imaginations. These are a cultural phenomenon, where women are realistically portraying their intelligence and humour (Chute, 2017). They have found a way and niche to challenge gender hierarchies, social constructs, gazes and perspectives within this form of popular culture (Lopes, 2006). Comics, as such, have become the perfect instrument for Nepali women artists to tell their autobiographical narratives that shift between reality and fiction, becoming both engaging and relatable to other women (Chute, 2010). 
In my interviews with the comic artists, none confirmed or believed that they are actively partaking in feminism or trying to create any form of social commentary/discourse. Kripa Joshi, for instance, explains it this way:

Even though I didn't start off to make Miss Moti a feminist, over time she has become more so, especially when I started the Miss Motivation series... Women are placed under a lot more pressure in terms of how they look or behave,... Miss Moti breaks those barriers by being a plus sized brown woman who encourages self acceptance. (K. Joshi, personal communication, February 22, 2019)

However, through their body of works, the Nepali women comic artists subtly depict the individual woman's struggles in their visual accounts. And it becomes clear that the artists are in a sense acting as agents of feminism through visual story telling (Chute, 2010). Their illustrations facilitate an expression of self, identity, and life that they as women and as personalities are part of a culture that is still highly patriarchal and restrictive in terms of women's position in society (Tamang, 2009; Leve, 2001). As such, they have proven that they are autonomous, and not swayed by social taboos or allow public opinions to dictate their works.

It has been my observation that even though comics in Nepal are far removed from the everyday of the general population ${ }^{11}$, Nepali women's comics have a specific readership or group of followers that have access to these comics and others (in the larger term of comics and graphic novels). In their own way, these women artists and their comics have come out in Nepal are representative of a small pocket of women and their issues and stories.

\section{REFERENCES}

Acharya, M. (1994). Political participation of women in Nepal, In Nelson, B. and Chowdhury, N. (eds.) Women and Politics Worldwide (pp. 478-495). New Haven: Yale University Press.

Anderson, A. (1993). Introduction. In Tainted Souls And Painted Faces: The rhetoric of fallenness in Victorian culture (pp. 1-21). Ithaca; London: Cornell University Press

Bajracharya, S. (2018). Nepalese Seasons: Rain and ritual. Available at: https://issuu.com/rmanyc/docs/ nepalase_seasons_-_combo-_96_ppi (Accessed 17 February 2020).

Bechdel, A. (2006). Fun Home: A family tragicomic. Boston: Houghton Mifflin.

Bhatt, R. M. (2013). Reading gender in Indian newspapers: Global, local or liminal. In Rudby, R. and Alsagoff, L. (eds.), The Global-Local Interface and Hybridity (pp. 121-132). Berlin: De Gruyter.

Boserup, E. (1970). Woman's Role in Economic Development. London: George Allen and Unwin.

Burathoki, K. (2013). Mountain Flight. Available at: https://kanchang.files.wordpress.com/2013/01/ mountainflight.jpg (Accessed 3 December 2018).

Burathoki, K. (2019). Breath In Breath Out. Available at: https://kanchang.wordpress.com/ (Accessed 3 December 2018).

Burathoki, K. (2019, February 21). Personal interview.

Chitrakar, M. (2012). Nepali Art. Issues miscellany. Patan, Nepal: Patan Museum.

Chitrakar, M. (2017). Nepali Paintings: Through the ages. Patan, Nepal: Patan Museum.

Chute, H. (2010). Graphic Women: Life narrative and contemporary comics. New York: Colombia University Press.

Chute, H. (2017). Why Comics: From underground to everywhere. New York: Harper.

Dean-Ruzicka. R. (2013). Mourning and melancholia in Alison Bechdel's Fun Home: A family tragicomic. Image Text, 7(2): n.p. (Accessed 13 September 2019).

Gellner, D., Pfaff-Czarnecka, J. and Whelpton, J. (eds.) (1997). Nationalism and Ethnicity in a Hindu State: The politics of culture in contemporary Nepal (Studies in Anthropology and History). New York, Routledge.

Joshi, K. (2007). Miss Moti and the Big Apple. Available at: https://www.missmoti.com/ (Accessed 17 October 2019).

Joshi, K. (2012). Miss Moti and Cotton Candy. Available at: https://www.missmoti.com/ (Accessed 17 October 2019).

Joshi, K. (2019, February 22). Email interview.

Kühl, S. (2016). The Angel in the House and Fallen Women: Assigning women their places in Victorian society. Open Education Resources. Available at: https://open.conted.ox.ac.uk/resources/documents/angel-houseand-fallen-women-assigning-women-their-places-victorian-society (Accessed 17 February 2020).

Lent, J. A. (2015). Asian Comics. Jackson, University Press of Mississippi.

Leve, L. (2007) 'Failed development' and rural revolution in Nepal: Rethinking subaltern consciousness and women's empowerment, Anthropological Quarterly, 80(1), 127-172.

\footnotetext{
${ }^{11}$ Though Nepal has a history of comics, particularly in satire and political caricature in national dailies, other forms of comics and graphic novels are not popular in circulation or a common medium read by a large body of the population (Lent, 2015).
}

(C) 2020 by Author/s 
Lopes, P. (2006). Sequential tarts: Gender intervention in American comic book culture, American Sociological Association Annual Meeting, Montreal, August 2006.

Merino, A. (2001). Women in comics: A space for recognizing other voices, The Comics Journal, 237, 44-48.

Pal, P. (1974). The Arts of Nepal (vol. II). Leiden, Netherlands: E. J. Brill.

Satrapi, M. (2003). Persepolis: The story of a childhood. New York: Pantheon Books.

Shrestha, P. (2009). Bad hair day. Available at: https://www.instagram.com/preenas/ (Accessed 20 February 2019).

Shrestha, P. (2011). Teacup in a storm. Available at: https:/ /www.instagram.com/preenas / (Accessed 20 February 2019).

Shrestha, P. (2018). Are we there yet? Creating Heroines żine. British Council, Nepal.

Shrestha, P. (2019). Self Love. In B. Tulachan, K. Burathoki, M. Lama, R. Lamichhane, P. Shrestha, P. Shrestha, S. Shrestha, U. Shrestha, Self Love. VIrangana Comics, Issue 1, Fine Print Publication, Kathmandu.

Shrestha, P. (2019, February 20). Personal interview.

Shrestha, P. (in press). Bhanchaghar. In B. Tulachan, K. Burathoki, K. Joshi, M. Lama, R. Lamichhane, K. Manandhar, D. Manandhar, P. Shrestha, P. Shrestha, S. Shrestha, Bhanchaghar (2020). VIrangana Comics, Issue 2, Fine Print Publication, Kathmandu.

Shrestha, S. (2003). Untitled 1. Kamana Gaijatra. Kathmandu, Nepal.

Shrestha, S. (2003). Untitled 2. Kamana Gaijatra. Kathmandu, Nepal.

Shrestha, S. (2003). Untitled 3. Kamana Gaijatra. Kathmandu, Nepal.

Shrestha, S. (2017). Burn bleed boom. Available at: https://www.instagram.com/macha_73/ (Accessed 20 February 2019).

Shrestha, S. (2018). Period. Available at: https://www.instagram.com/macha_73/ (Accessed 20 February 2019).

Shrestha, S. (2019). The Permission Game. In B. Tulachan, K. Burathoki, M. Lama, R. Lamichhane, P. Shrestha, P. Shrestha, S. Shrestha, U. Shrestha, Self Love. VIrangana Comics, Issue 1, Fine Print Publication, Kathmandu.

Shrestha, S. (2019, February 20). Personal interview.

Shrestha, S. (2019, July 24). Personal interview.

Streeten, N. and Tate, C. (2018). The Inking Woman: 250 years of women cartoon and comic artists in Britain. Brighton, UK: Myriad Editions.

Tamang, S. (2009). The politics of conflict and difference or the difference of conflict in politics: The women's movement in Nepal, Feminist Review, 91, 61-80.

Tulachan, B. (2019). To Love. In B. Tulachan, K. Burathoki, M. Lama, R. Lamichhane, P. Shrestha, P. Shrestha, S. Shrestha, U. Shrestha, Self Love. VIrangana Comics, Issue 1, Fine Print Publication, Kathmandu.

Tulachan, B. (2019, February 15). Personal interview.

Tulachan, B., Burathoki, K., Lama, M., Lamichhane, R., Shrestha, P., Shrestha, P., Shrestha, S., Shrestha, U. (2019). Self Love. VIrangana Comics, Issue 1, Fine Print Publication, Kathmandu.

Upadhya, S. (1996). The status of women in Nepal - 15 years on. Studies in Nepali History and Society, 1(2), 423-454.

Whelpton, J. (2005). A History of Nepal. Cambridge: Cambridge University Press.

Wildermuth, N. (2009). Media events and gendered identities in South Asia: Miss World going 'Deshi'. In N. Couldry, A. Hepp and F. Krotz (eds.), Media Events in a Global Age (pp. 156-171). London: Routledge.

Citation: Shrestha, P. (2020). Nepali Women in Comics. Feminist Encounters: A Journal of Critical Studies in Culture and Politics, 4(1), 12. https://doi.org/10.20897/femenc/7916 